\title{
The Frozen Food Quality of Sukoharjo Elementary School Area
}

\author{
Kartika Pibrianti \\ Universitas Veteran Bangun Nusantara \\ Sukoharjo, Indonesia \\ dkartika.02@gmail.com
}

\begin{abstract}
Food availability and safety are basic of human rights. The students are a risky group to become the unsafe consumers of snacks because of the threat of biological or chemical contamination that is disrupted the health. Sausages and nuggets are the examples of frozen foods that is the children like. The number of frozen food vendors in various types in the school environment is a concern for the parents about the food safety. This research uses a qualitative method with a descriptive approach. The data of the research is primary data from the examination of microbial contamination and food chemistry conducted in the Environmental Health Laboratory of Sukoharjo. The population in this research were all frozen snacks that is sold in the elementary school area of Sukoharjo on July 2018. The sampling method was done purposively. The results showed that of the 10 types of frozen foods, 6 of them were positive for E. coli, namely otak-otak ikan (one of the frozen food that made from fish meat), otakotak ayam (one of the frozen food that made from chiken meat), shrimp balls, tempura, noodles sausage, and beef sausages then 4 of them are negative, they are fish balls, star nuggets, red tempura and the ice cream nuggets it means the ingredients and tools that is used to make this foods are not contaminated with E.coli bacteria. So that 4 out of 10 the tested foods did not meet the quality standards regarding the maximum limits of microbial and chemical contamination in food. Based on the examination of dyes, the negative results were obtained, both of the Methanil Yellow and Rhodhamin B dyes and fulfilled health requirements.
\end{abstract}

Keywords-e.coli, frozen, methanil yellow, rhodamin b

\section{INTRODUCTION}

Healthy and safety food is an important factor to improve the public health. Food quality and safety on a biologically, chemically and physically must always be maintained, in order that the people as users of food products avoid diseases caused by the food, foodborne illness and food poisoning. Frozen food is the result of food preservation methods by lowering the temperature to freezing which aims to slow down the decay process. Frozen food was originally made for someone who was very busy, unwilling or unable to prepare food for himself [1]

Changes of lifestyles encourage the peoples to consume the frozen food products that are adapted to eating patterns from developed countries. The research that is conducted by [1]. shows that the taste factors are the main consideration, followed by convenience, packaging, price, brand, and presentation time for the consumers. Food safety is a global and national issue. Food availability and safety are basic the human rights. This problem is currently a global concern because hundreds millions of people are reported to suffer from the food poisoning. Globally in 2015 it was found that 2 million people died each year because of the unsafe food.
Whereas in Indonesia there were 2,500 people died and 411,500 were sick [2]

One community group that often experiences problems due to street food poisoning is school children. Many popping snacks with cute, unique shapes and striking colors that make the childrens more interested to buying it. While the attractive appearance does not guarantee that the snacks are safe and even suitable for consumption. Snacks are not infrequently that is made by using hazardous chemicals either in the form of dyes or preservatives which can cause poisoning or giving the other dangerous diseases if consumed continuously. Not only the chemicals that can "poison" snacks of the children, there are also germs that can contaminate these snacks if they are not made and stored in the right way can give rise to nausea, vomiting and diarrhea.

Snack hold up an important role in providing energy and other nutrients for school-age children. Consumption of snacks for school-age children needs to be considered because of high children's activities. Consumption of child snacks is expected to contribute energy and other nutrients that are useful for the growth of children [4]

Extraordinary Events (KLB) poisoning has occurred in 4 Subdistricts of Sukoharjo Regency, including at Tawangsari, Weru, Nguter, and Gatak. Snack poisoning in schools in the last 3 years occurred in Gatak District of Sukoharjo in 2015 precisely at Trangsan 3 Gatak Elementary School. Along with the development of lifestyle and food technology, there are many rows of food vendors in the school area whose food security cannot be ascertained yet, especially schools whose geographical location is in urban areas. The modernization era that is supported by many pocket money from their parents encourages the students to choose delicious snacks.

Based on the description about it is considered important to analyze the quality of snacks especially on frozen food which is a favorite snack of elementary school children to find out the feasibility or limits of microbial contamination in accordance with the Regulation of the Food and Drug Supervisory Agency of the Republic of Indonesia Number: HK 00.06.1.52.4011 concerning on the Maximum Limit of Microbial Contamination and Chemistry in Food and the feasibility of food for coloring agents in accordance with the RI Minister of Health Regulation No. 722 / Menkes / Per / IX / 88 concerning of Supplementary Foods that are Prohibited. 


\section{METHOD}

The type of this research is used qualitative with an observational descriptive approach. The population in this research were all frozen snacks sold in the elementary school area of Sukoharjo in July 2018. The sampling method was done purposively. Inclusion criteria consist of: 1. Snack vendors that are selling in all the elementary schools at the City area 2. Sample traders are food traders who serve and sell when the research takes place in large quantities 3. Food samples are frozen food products sold by the vendor samples 4 . The type of frozen food that is most preferable by the children. Te data types of this research is the form of E. coli identification results and analysis of coloring content of 10 selected frozen foods include fish brains, chicken brains, shrimp balls, fish balls, tempura, sausage noodles, star nagget, red tempura, beef sausages and nuget ice cream. Measurements were made at the Regional Environmental Health Laboratory of Sukoharjo. The results of the research data were analyzed descriptively.

The results of E.coli examination in 10 samples obtained 6 positive samples of E.coli bacteria, namely samples of otak-otak ikan (one of the frozen food that is made from fish meat), otak-otak ayam (one of the frozen food that is made from chiken meat), shrimp balls, tempura, sausage noodles, and beef sausages and 4 negative samples, namely fish balls, Star nuggets, red tempura, and ice cream nuggets means the ingredients and tools that used are not contaminated with E.coli bacteria. So that 4 of the 10 samples tested did not fulfilling of the standard quality according to the Regulation of the Head of the Food and Drug Supervisory Agency of the Republic of Indonesia Number: HK 00.06.1.52.4011 About the Maximum Limit of Microbial Contaminants and Chemicals in Food.

The results of examination of dyes in 10 samples obtained negative results, both Methanil Yellow and Rhodhamin B coloring agents and fulfilling health requirements, in accordance with the Republic of Indonesia Minister of Health Regulation No. 722 / Menkes / Per / IX / 88 concerning of the Supplementary Foods that are Prohibited

\section{RESULT AND DISCUSSION}

Examination of E.coli bacteria was carried out on 10 samples of frozen food namely otak-otak ikan, otak-tak ayam, shrimp balls, fish balls, tempura, sausage noodles, star nuggets, red tempura, beef sausages and ice cream nuggets. The examination results ranging from approximate tests to complete the tests getting positive results of E.coli bacteria for samples of otak-otak ikan (one of the frozen food that made from fish meat), otak-otak ayam (one of the frozen food that made from chiken meat), shrimp balls, tempura, sausage noodles, and beef sausages means that the ingredients and tools that used are contaminated with bacterial E .coli. Whereas for fish ball samples, star nuggets, red tempura, and ice cream nuggets get negative results, it means the ingredients and tools that used are not contaminated with E.coli bacteria. The treatment of food handlers and storage of food and beverages is not the right way to handle because 6 of the 10 samples tested got positive results of E.coli bacteria, in there the researcher find the results that do not qualify with the Regulation of the Head of the Food and Drug Supervisory Agency of the Republic of Indonesia Number: HK 00.06.1.52 .4011 About the Maximum Limits of Microbial Contaminants and Chemicals in Food.

Generally, based on the observations and interviews with hawker food vendors in the school area, it is known that the education of these traders is mostly on the middle level so that knowledge of food sanitation is very low. Clean water and soap facilities are not available because they sell around using motorbikes and they do not have the awareness to wash their hands before serving food which is also caused by ignorance. They are in school until the break and after that they move to the place of sale by walk around.

E.coli bacteria are commonly found in the digestive tract of humans and animals, transmission of E.coli bacteria through food and water contaminated with feces. Diseases caused by E.coli are diarrhea, sepsis and meningitis in infants. This is certainly a concern of all parties because of the sample tested $60 \%$ the results are negative, meaning that the food is not suitable for consumption especially for school children who are still very vulnerable to immune against microorganisms that will develop in their bodies.

The dyeses tests (Methanil Yellow and Rhodhamin B) were carried out on 10 frozen food samples namely otakotak ikan (one of the frozen food that made from fish meat), otak-otak ayam (one of the frozen food that made from chiken meat), shrimp balls, fish balls, tempura, sausage noodles, star nuggets, red tempura, beef sausages and ice cream nuggets. The results of the examination of dyes in 10 samples obtained the negative results, both Methanil Yellow and Rhodhamin B dyes agents and fulfilling health requirements, according to the Republic of Indonesia Minister of Health Regulation No. 722 / Menkes / Per / IX / 88 concerning of the Supplementary Foods that are Prohibited.

\section{CONCLUSION}

The results of E.coli examination in 10 samples obtained 6 positive samples of E.coli bacteria, namely samples of otak-otak ikan (one of the frozen food that is made from fish meat), otak-otak ayam (one of the frozen food that is made from chiken meat), shrimp balls, tempura, sausage noodles, and beef sausages and 4 negative samples, namely fish balls, Star nuggets, red tempura, and ice cream nuggets means the ingredients and tools that used are not contaminated with E.coli bacteria. So that 4 of the 10 samples tested did not fulfilling of the standard quality according to the Regulation of the Head of the Food and Drug Supervisory Agency of the Republic of Indonesia Number: HK 00.06.1.52.4011 About the Maximum Limit of Microbial Contaminants and Chemicals in Food.

The results of examination of dyes in 10 samples obtained negative results, both Methanil Yellow and Rhodhamin B coloring agents and fulfilling health requirements, in accordance with the Republic of Indonesia 
Minister of Health Regulation No. 722 / Menkes / Per / IX / 88 concerning of the Supplementary Foods that are Prohibited

\section{ACKNOWLEDGEMENT}

The author would like to thank to the leader of University of Veteran Bangun Nusantara Sukoharjo.

\section{REFERENCES}

[1]. Lovell, Richard. Product Attributrs and Consumer's Repurchase Decision on Frozen Ready to Eat Meals: a Study on Consumers in Selected Hypermarkets in Bangkok.,2011.

[2]. BPOM RI. Laporan Tahunan. Jakarta : Badan Pengawas Obat dan Makanan Republik Indonesia. 2015.

[3]. Kemenkes RI. Pedoman Keamanan Pangandi Sekolah Dasar. Direktorat Bina Gizi Ditjen Bina Gizi dan Kesehatan Ibu dan Anak Kementrian Kesehatan . 2011

[4]. Sutardji., M. Azinar.. Tingkat Konsumsi Energi dan Konsumsi Protein serta Hubungannya dengan Status Gizi Anak Asuh Usia 1018 Tahun (Studi pada Penyelenggaraan Makanan di Panti Asuhan 